\title{
The Determinants of Livelihood Diversification Strategies in Qecha Bira Woreda, Kambata Tambaro Zone, Southern Ethiopia
}

\author{
Tariku Lorato \\ Department of Economics in College of Business and Economics, Dilla University, Ethiopia
}

\begin{abstract}
Rural households engage in to livelihood diversification activities to ensure their food needs. The livelihood diversification is determined by different factors. This study investigated the determinants of these strategies in Qecha Birra woreda. Multistage sampling technique was employed to select 355 household heads of study area. The descriptive statistics result indicated that majority of the rural households $(41.6 \%)$ engaged into on farm activity. However, the rest $22.54 \%, 21.41 \%$ and $14.37 \%$ combine on farm with off farm, non-farm and off farm plus non-farm livelihood activities respectively. This shows that agriculture is still dominant livelihood activity in the study area. Multinomial logistic regression model result demonstrated sex of the household heads, age, education status, training, and extension service, credit access, livestock ownership and market access are found to be significant determinants of the diversification. Therefore due attention should be given to strengthen livelihood diversification strategies so as to improve food security.
\end{abstract}

Keywords: Livelihood, Diversification, Determinants, multinomial Logit model, Food security

DOI: $10.7176 / \mathrm{JESD} / 10-9-02$

Publication date:May $31^{\text {st }} 2019$

\section{INTRODUCTION}

Agriculture is an important sector for the majority of the rural populations' livelihood. It has been the predominant activity for most rural households in Sub-Saharan African countries which offers a strong option for stimulating growth, overcoming poverty and improving food security (WB, 2008). However, the farming as a primary source of income has become failed to guarantee a sufficient livelihood for farming households (Babatunde, 2013). This is because the agricultural sector in the region is highly characterized by drought, erratic rainfall, decreasing farm sizes, low levels of output per farm, and a high degree of subsistence farming (Jirstrom et al., 2011). This has led to decline in agricultural productivity and food security.

Ethiopia is one of the most famine prone countries in Sub-Saharan Africa, has a long history of famine and food shortages. The food insecurity situation of the country has been increasing and the estimated number of food insecure people increased from 5.6 million in 2016 to 8.5 million in 2017 (FAO, 2017). The majority of the population have engaged in agricultural economic activities and agriculture accounts for $41 \%$ of the GDP (MoFED, 2016). However, the sector has been continually failed to meet the growing food need of the rural population. A significant number of people suffer from food shortage and poverty (Tezera, 2010). As stated in Workneh (2008) and Shitarek (2012) the causes of food insecurity in Ethiopia are drought, frequently occurring poverty, population growth, environmental degradation, diminishing of land holdings, lack of on-farm technological innovations and lack of non-farm/off-farm income generating sources.

To solve the problem of food insecurity and poverty, Ethiopian government has issued Food Security Program (FSP) under the umbrella of Plan for Accelerated Sustainable Development to End Poverty (PASDEP) and embarked on the preparation of long term (2015/16 to 2029/30) national development plan that would integrate the SDGs into the plan. The SDG-integrated GTP II is showing encouraging results. However; Severe drought occurred over broad regions of Ethiopia near the launch of the implantation of the GTP II (2015/16) caused severe food insecurity. Thus, implementations of the policies are envisaged to ensure food security in the whole country and at every household level to eradicate poverty in all its forms. Efforts have been made to improve the production and productivity of agriculture through research, technology adaptation and generation, extension services and input supply but there are no large-scale improvements in the living conditions of rural populations (NPC, 2017).

Livelihood diversification is viewed as a response to the failure of agriculture to provide an adequate livelihood for significant share of rural inhabitants. So, diversification remains crucial for tackling food insecurity irrespective of the form it may take either farm based, off farm/non-farm or mixed (Ellis and Allison, 2004). In this case livelihood diversification remains the most effective weapon for addressing the seemingly difficult food insecurity across the globe (Swift and Hamilton, 2001 cited in Tezera, 2010); and it is determined by different factors.

The empirical literature shows that the determinants of livelihood diversification strategies in Ethiopia in general and study area in particular at local context were less researched. Ambachew et al., (2016) employed multinomial logit to empirically examine the determinants of rural household livelihood diversifications strategy in South Gondar zone, using cross sectional data. Birhanu and Getachew (2017) investigated livelihood diversification status, challenges and factors influencing pastoral household's engagement in livelihood 
diversification activities in Bale zone, Ethiopia pastoral livelihood by using multinomial logistic model.

The above studies emphasized on the determinants of livelihood diversification strategies at zone level and didn't classify determinants of livelihood diversification according to socio-economic variable, land characteristics, demographic characteristics and institutional variables. This classification is very important because the variables in each classification vary from place to place. Therefore, this study investigated the determinants of livelihood diversification strategies in Kecha BiraWoreda of KembataTambaro Zone, Southern Ethiopia. Specifically, this study answered the following research questions.

$\checkmark$ Which livelihood diversification activities are practiced by rural households in study area?

$\checkmark$ What factors determine livelihood diversification strategies in the study area?

\section{METHODOLOGY OF THE STUDY}

\section{Research design, data type and Methods of data collection}

Research design is a logical structure for conducting a particular investigation (De Vaus2001). The selection of research design rests primarily on the specific question a researcher seeks to investigate and the applicability of such a design (Berger et al, 2009). To this end, this study employed cross-sectional survey design because it is economical in terms of costs and time due to its ability to draw generalization about large population on the basis of representative sample(Krishna and Ranga, 2005).In order to achieve the objectives, both qualitative and quantitative data types were used. To collect data the study used both primary and secondary sources. The primary data was collected through survey from representative respondents among target population of the study area by using questionnaire and interview of key informants. The secondary data were collected from review of different document such as research works, office reports and documents, journal articles written by different scholars on related issues.

\section{Sampling Techniques and Sample Size Determination}

The study used multi-stage sampling technique which is a combination of purposive, stratification, simple random and systematic sampling method so as to select Woreda, sample kebeles and households. In the first stage out of eight woredas found in Kembata Tembaro Zone, Kecha Bira Woreda was selected purposively, considering sever food insecurity situation of the woreda. The Woreda experiences food deficit every year where the food gap is covered by food aid and the community in the area is highly affected by food insecurity problem (WAO, 2017). In the second stage the total of 21 rural kebeles in the study area were classified in to three strata based on their agro ecological zones. Accordingly, 28.6\%, 33.3\% and 38.1\% samples were selected from Dega, Woinadega and dry Woina Dega zones respectively.

In the third stage, simple random sampling technique was used to select kebeles from each agro-ecological zone taking into consideration the number of kebeles in each agro-ecological zone. Therefore, for the purpose of this study, kebeles that are being considered are: Wererama, Awaye, Ashera, and Eta. In the fourth stage, Yamane (1967) formula was used to determine sample size as:

$$
\mathrm{n}=\frac{N}{1+N(e) 2}
$$

Where, $\mathrm{N}$ is the total population, $e$ (margin of error) is $0.05(5 \%)$ while the confidence level is $95 \%$. Using the total population of selected kebeles of 4046 and error margin of 0.05 , the sample size was calculated as follows.

$\mathrm{n}=\frac{4046}{1+4046(0.05) 2}=364$. Hence, sample size of 364 was taken.

Then, the sample size of households from each sample kebele was calculated by using the probability proportional to sample size. Finally, the individual households were selected by using systematic sampling method. Accordingly, sample size for each kebele determined is indicated in table-1 below:

Table 2: Sample size determination for respondent households

\begin{tabular}{lllcc}
\hline S/ & Selected kebele & Location & Number of HHs & $\begin{array}{c}\text { proportion of sampled HHs } \\
\mathrm{n}_{\mathrm{k}}=\mathrm{NkS} / \sum \mathrm{N}\end{array}$ \\
\hline 1 & Wererama & Dry woinadega & 996 & 89 \\
2 & Awaye & Dry woinadega & 942 & 85 \\
3 & Ashira & Wet woinadega & 1067 & 96 \\
4 & Eta & Dega & 1041 & 94 \\
\multicolumn{2}{l}{ Total } & & 4046 & 364 \\
\hline
\end{tabular}

Source: Own computation, 2018

Methods of Data Analysis

To analyze the data, both descriptive and inferential statistics were used. To identify and examine livelihood activities that are pursued by rural households in the study area descriptive statistics like percentages, mean, standard deviation, maximum and minimum were used. The F-test and Chi-square test statistics were also employed to differentiate statistical significance of variables on livelihood diversification strategies with respect to the continuous and discrete explanatory variables. To analyze the determinants of livelihood diversification 
multinomial logit model was used.

\section{The Econometric model specification and Estimation procedure}

In this study; the dependent variable livelihood diversification strategies were classified in to four (on farm only, on farm + off farm, on farm + non-farm and on farm + off farm + non-farm).

When there is a dependent variable with more than two alternatives among which the decision maker has to choose (i.e. unordered qualitative or polytomous variables), the appropriate econometric model would be either multinomial logit or multinomial probit regression model. Regarding estimation, both of them estimate the effect of explanatory variables on dependent variable involving multiple choices with unordered response categories (Greene, 2003). However, multinomial probit is rarely used in empirical studies due to estimation difficulty imposed by the need to solve multiple integration related to multivariate normal distribution (Chilot, 2007). However, it is worth noting that this model suffers from the assumption that the choice probabilities implied by the model must satisfy an Independence of Irrelevant Alternatives (IIA) property. The Independence of Irrelevant Alternatives (IIA) assumption means that adding or deleting alternative outcome categories does not affect the odds among the remaining outcomes. This means that the ratio of probabilities of any two choices (in response categories) will be the same regardless of what the other alternatives are.

However, Wassie et al, (2008) stated that multinomial logit model is an important model to examine the determinants of household livelihood diversification strategy among the alternative livelihood strategies. Accordingly, multinomial logit model is employed to identify the determinants of livelihood diversification strategies. In this model, the choice probabilities are dependent on individual characteristics and the model estimates relative probabilities. Hence, for the $\mathrm{i}^{\text {th }}$ respondent faced with $\mathrm{k}$ choices, we assume that the indirect utility of a choice is superior to other choices. In equation below, $\mathrm{P}^{\mathrm{i}}=0$, if the individual is participating in agriculture strategy choice alone; $\mathrm{P}^{\mathrm{i}}=1$, if the individual is participating in agriculture and off- farm combination strategy and so on, where $\mathrm{P}^{\mathrm{ik}}$ is the probability of an participation of the $\mathrm{k}^{\text {th }}$ choice; kis livelihood strategy that the $\mathrm{i}^{\text {th }}$ household chooses to maximize its utility category. Each of the responses will fall into one of the categories with $\mathrm{P}^{\mathrm{ik}}$ probabilities. An individual will then choose the livelihood activity that offers the highest utility. Thus, to identify the determinants of rural household's livelihood diversification strategies, multinomial logit model was employed (Green, 2003) and specified as follows:

$$
p_{(k=j)}=\frac{e^{z i \beta j}}{\sum_{j=0}^{k} e^{z i \beta j, j=0,1,2, \ldots j},}
$$

Where: $\mathrm{K}=$ Polytomous outcome variable with categories coded from $0 \ldots \mathrm{J}$.

$\mathrm{P}=$ represents the probabilities of the $\mathrm{j}^{\text {th }}$ case falls in category $\mathrm{k}$

$\mathrm{e}$ is natural $\log ; \beta$ coefficients associated with $\mathrm{Z}^{\mathrm{i}}$ independent variables.

Equation (1) can be normalized to remove indeterminacy in the model by assuming that $\beta 0=0$ and the probabilities can be estimated as:

$\operatorname{Prob}(K i=j / x i)=\frac{e^{z_{i \beta j}}}{1+\sum_{j=0}^{k} e^{z_{i \beta j}}} j=0,1,2 \ldots j, \beta$

Estimating equation (2) yields the $\mathrm{J} \log$-odds ratios

$\ln \left(\frac{P i j}{p i k}\right)=z i^{\prime}(\beta j-\beta k)=z i^{\prime} \beta j$, if $k=0$.

The dependent variable is therefore the log of one alternative relative to the base alternative. The multinomial logit coefficients are difficult to interpret, and associating the $\beta \mathrm{j}=$ with the $\mathrm{j}^{\text {th }}$ outcome is tempting and misleading. To interpret the effects of explanatory variables on the probabilities, marginal effects are usually derived (Greene, 2003):

$\delta j=\frac{\delta j}{\delta z i}=P j\left[\beta j-\sum_{k=0}^{j} P k \beta k\right\rceil=P j\left(\beta j-\beta^{-}\right)$

The marginal effects measure the expected change in probability of a particular choice being made with respect to a unit change in an explanatory variable (Greene, 2003).

The independent variables expected to affect diversification of livelihood strategy are: - demographic characteristics (include age, marital status, sex, family size and education status of household). The socioeconomic variables (include number of livestock, farm land size, and available technical skills of HH). Land characteristics (includes Agro ecology) and Institutional variables (includes credit access, market access and training and extension service) 
Table 3: Summary of definition, measurements of variables and its expected sign

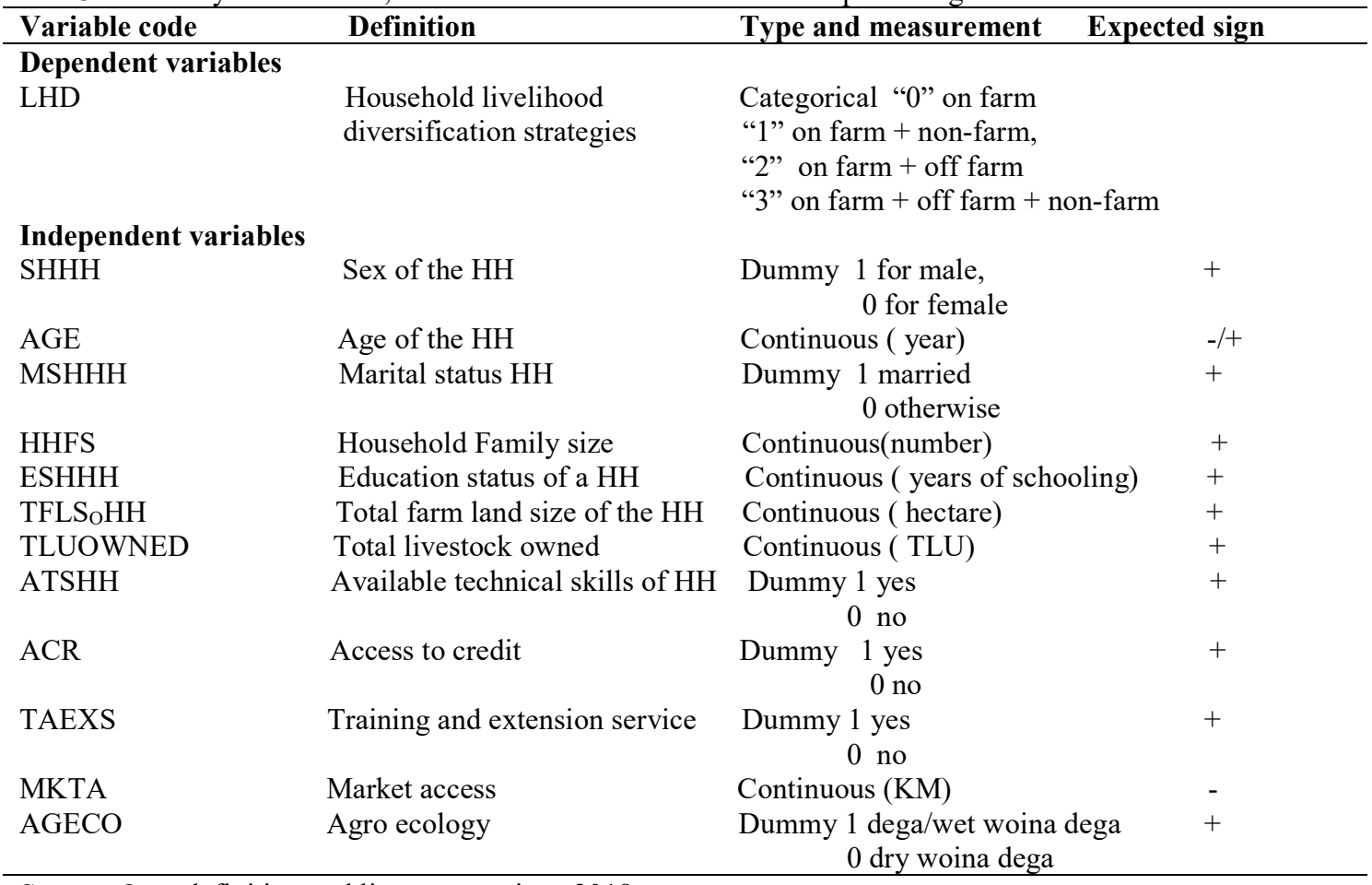

Source: Own definition and literature review, 2018

\section{RESULTS AND DISCUSSION}

In the study the sample size calculated was 364 but data was collected from 355 households due to unwillingness of selected unit to cooperate and provide some information requested. The response rate is $97 \%$. Therefore, this study was analyzed by 355 sampled households in the study area.

Results of Descriptive Statistical Analysis

Rural households in the study area engaged into different combination of livelihood diversification activities. Even though, agricultural land is declining from time to time, a significant part of the sampled respondents still engaged into on farm activities. As it can be seen from the survey results on table 2, in the study area out of 355 sampled respondents, $41.69 \%$ participated into on-farm activity and $22.54 \%$ respondents participated in both on-farm + off-farm, $21.41 \%$ respondents participated into on-farm + non-farm diversification strategy and the rest $14.37 \%$ respondents engaged into on farm + off farm + non-farm diversification strategies.

As key informants also explained that, households in the study area engaged in different livelihood activities like on farm (crop production and animal husbandry activities), off farm activities (local daily wage labor at village level, the agricultural work at another person's farm in return for part of the harvest in kind and firewood and charcoal selling), and non-farm activities (Handicraft activities, carpentry and house mudding), petty trade (grain trade, fruits and vegetables trade), selling of local drinks, trading of small ruminants and cattle, wheelbarrow, Cart and remittance transfers within and across nations). Thus, rural farm households in the study area have followed different combination of these livelihood activities to pursue their livelihood strategies. However, the earnings from these livelihood activities were low. This was constrained by poor socioeconomic infrastructures (educational facilities, health institutions, and veterinary facilities) and poor market and market information, availability of road and transport service, lack of skill training, poor access to sufficient credit. These influenced the food security situation of the study woreda.

Table2: Distribution of sampled household by livelihood diversification strategies

\begin{tabular}{lccc}
\hline & \multicolumn{3}{c}{ Livelihood Diversification Strategies } \\
\hline & Frequency & Percent & Cumulative Percent \\
\hline On- farm & 148 & 41.69 & 41.69 \\
On farm + off farm & 80 & 22.54 & 64.23 \\
Off-farm + Non-farm & 76 & 21.41 & 85.63 \\
On-farm + Off-farm +Non- farm & 51 & 14.37 & 100.0 \\
Total & 355 & 100.0 & \\
\hline
\end{tabular}

Source: own survey computation, (2018). 


\section{Econometric Model Results}

As specified in the methodology part of this research, multinomial logistic regression model was used to identify factors affecting livelihood diversification strategies in the study area. Under this section important variables (demographic, socio-economic, institutional and land characteristic) which were hypothesized to influence the households' decision to participate into different livelihood diversification strategies are considered. The analysis was made by using; STATA 13version. The hypothesized explanatory variables were tested for the existence of Independence of irrelevant alternative (IIA) and Multicollinearity.

Independence from irrelevant alternatives (IIA): In the model, Hausman test was undertaken to check for the existence of IIA. The HM test showed that there was no violation of the IIA. The chi-square which are not significant and prob $>\mathrm{chi}^{2}$ for on farm + off farm, on farm + non-farm and on farm + off farm + non-farm were chi ${ }^{2}$ of 6.78 and prob $>\mathrm{chi}^{2}$ of $0.9999, \mathrm{chi}^{2}$ of 9.14 and prob $>\mathrm{chi}^{2}$ of 0.9991 and chi2 of 1.21 and prob $>\mathrm{chi}^{2}$ of 1.0000 respectively.

\section{Multicollinearity and degree of association}

Before conducting econometric analysis it is vital to look into the problem of multicollinearity among the continuous explanatory variables and verify the degree of associations among dummy explanatory variables which otherwise, the parameter estimate would seriously be affected by the existence of multicollinearity among variables. To this end, the variance inflation factor (VIF) and contingency coefficients were used to test the degree of multicollinearity among the continuous variables and to check the degree of association among the discrete variables. The values of VIF for continuous variables were found to be small (i.e. VIF values less than 10). As a rule of thumb, if the VIF of a variable exceeds 10, that variable is said to be highly collinear (Gujarati, 2004). Based on the VIF result, in this study the maximum VIF value 3.69 indicated that there is no problem of multicollinearity among the variables in this study. Also, according to (Gujarati, 2004), contingency coefficient is a chi-square based measure of association where a value 0.75 or above indicates a stronger relationship between explanatory variables. Accordingly, the results of the computation revealed that the maximum value of contingency coefficient was 0.62 indicating no serious problem of association among discrete explanatory variables.

The goodness-of-fit determines the accuracy of the model prediction approximates to the observed data. Wald Chi- square test shows the overall goodness of fit of the model at $1 \%$ probability level. Wald Chi-square test shows that at least one of the predictors' regression coefficients is not equal to zero. From the results in the Table 3 , a Wald $\mathrm{chi}^{2}$ statistic of 178.68 with a Chi-square distribution of $($ Prob $>$ chi2 $)=0.0000$ is significant at less than $1 \%$ probability level shows at least one of the explanatory variables in the model has significant effect on household's livelihood diversification strategies and that the explanatory variables jointly influence household's livelihood diversification strategies.

Determinants of livelihood diversification strategies of rural farm households

Table 3: Multinomial logit model result

\begin{tabular}{|c|c|c|c|c|c|c|c|c|c|}
\hline \multirow[t]{3}{*}{ Variables } & \multicolumn{9}{|c|}{ Rural livelihood diversification strategies } \\
\hline & \multicolumn{3}{|c|}{ On farm + non-farm } & \multicolumn{3}{|c|}{ On farm + off farm } & \multicolumn{3}{|c|}{ On farm + off farm + non-farm } \\
\hline & Coet & P-value & $\begin{array}{l}\text { Marginal } \\
\text { effect }\end{array}$ & Coef. & P-value & $\begin{array}{l}\text { Marginal } \\
\text { effect }\end{array}$ & Coef. & P-value & $\begin{array}{c}\text { Marginal } \\
\text { effect }\end{array}$ \\
\hline \multicolumn{10}{|c|}{ Demographic factors } \\
\hline SHHH & 2.697 & $0.045 * *$ & 0.463 & 0.682 & 0.585 & -0.077 & 2.358 & 0.163 & 0.00819 \\
\hline AGE & -0.176 & $0.007 * * *$ & -0.020 & -0.212 & $0.002 * * *$ & -0.018 & -0.229 & $0.002 * * *$ & -0.00093 \\
\hline MSHHH & 1.004 & 0.178 & 0.363 & 1.119 & 0.138 & -0.307 & 1.327 & 0.110 & 0.01064 \\
\hline HHFS & 0.154 & 0.348 & 0.029 & 0.072 & 0.680 & -0.0041 & 0.177 & 0.347 & 0.00084 \\
\hline ESHHH & 0.448 & $0.008 * * *$ & 0.054 & 0.495 & $0.004 * * *$ & 0.037 & 0.933 & $0.000 * * *$ & 0.00581 \\
\hline \multicolumn{10}{|c|}{ Socio economic factors } \\
\hline ATSHH & -0.328 & 0.740 & -0.085 & 0.073 & 0.943 & 0.049 & -0.755 & 0.482 & -0.00579 \\
\hline TFLSOHH & 1.213 & 0.239 & 0.191 & 0.971 & 0.339 & 0.038 & 1.572 & 0.142 & 0.00742 \\
\hline TLUOWNEL & -1.134 & $0.023 * *$ & -0.149 & -1.190 & $0.016 * *$ & -0.086 & -1.277 & $0.017 * *$ & -0.00446 \\
\hline \multicolumn{10}{|c|}{ Institutional factors } \\
\hline TAEXS & 3.698 & $0.000 * * *$ & 0.465 & 3.115 & $0.001 * * *$ & 0.112 & 6.059 & $0.000 * * *$ & 0.04649 \\
\hline ACR & 3.360 & $0.001 * * *$ & 0.410 & 3.015 & $0.002 * * *$ & 0.125 & 4.777 & $0.000 * * *$ & 0.02774 \\
\hline MKTA & -0.316 & $0.093^{*}$ & -0.032 & -0.415 & $0.035 * *$ & -0.038 & -0.502 & $0.017 * *$ & -0.00246 \\
\hline \multicolumn{10}{|c|}{ Land characteristics } \\
\hline AGECO & 0.508 & 0.587 & 0.105 & 0.205 & 0.827 & -0.017 & -0.331 & 0.740 & -0.00588 \\
\hline CONS & 1.479 & 0.557 & & 8.850 & 0.000 & & -2.402 & 0.434 & \\
\hline
\end{tabular}

Number of obs. $=355$, Wald chi2 $(39)=178.68$, Prob $>$ chi2 $=0.000 * * *$, Log likelihood $=-206.8$, Pseudo R2= 0.55 .

Source: Own survey, 2018. ***,**,* indicates significant at $1 \%, 5 \%$ and $10 \%$ probability levels respectively. 


\section{Model results interpretation}

Multinomial logit model result indicated that, among 12 hypothesized explanatory variables, 7 variables were found to be significant influence on livelihood diversification strategies of on farm + non-farm, on farm + off farm and on farm + off farm + non-farm activities respectively. These include Sex of the household head (SHHH), Age of household head (AGE),Education status of household (ESHHH), Socio economic factors (Total livestock owned (TLUOWNED) and Institutional factors (Training and extension service (TAEXS), Access to credit (ACR), and Market access (MKTA) were determining farmer's participation into different livelihood diversification strategies (see table-3).

It has to be noted that the multinomial logit estimates are reported for three of the four categories of livelihood strategies. The first alternative (i.e. on farm livelihood strategy) was used as base category against which the choices of the other three alternatives were considered. The plausible implication and marginal effects of the significant explanatory variables on the households' livelihood diversification strategies are presented as follows: Sex of the household head (SEX): As expected, the sex of household head positively and significantly determined engagement of livelihood diversification strategies into on farm + non-farm at $5 \%$ probability level. The result implies that male headed households are more likely to diversify the livelihood strategies into on farm + non-farm than female headed households. On the other hand female headed households are less likely to diversify the livelihood strategies. The possible reasons are due to cultural factors that females are assigned to care the child, perform home works and other social roles. Marginal effect results of the model demonstrated that, other variables being kept constant, the likelihood of male headed households' choice of livelihood diversification into on farm + non-farm increase by $46.3 \%$ than female household head. This is consistent with the study by Ambachew et al., (2016), male headed household's participated more than female household head, because in developing countries females are constrained by cultural challenges and they engaged themselves in house activities.

Age (AGE): The model result indicated that, as expected the age of household head influenced negatively and significantly the choice of on farm + non-farm, on farm + off farm and on farm + off farm + non-farm livelihood activities at $1 \%$ probability level. This indicates that those farmers with old age are less likely to diversify the livelihood strategies into on farm + off farm, on farm + non-farm and on farm + off farm + non-farm activities. This is because as the household heads get older, they become inactive and expected to be risk averse and hence depend more only on their own farm income. Marginal effects results of the model revealed, other variables being kept constant, the likelihood of a rural households choice of on farm + non-farm, on farm + off farm and on farm + off farm + non-farm livelihood activities decrease by $2 \%, 1.8 \%$ and $0.093 \%$ respectively, for increasing one additional year. This is consistent with study by Tassew (2002); as the household heads get older, they are expected to be less active and hence rely more on the farm than off farm/non-farm income but contradicts with(Birhanu and Getachew, 2016); age of household head influenced positively and significantly the household's livelihood diversification strategy.

Education status of household (ESHHH): As expected, the variable education positively and significantly related with the households livelihood diversification into on farm + non-farm, On farm + off farm and on farm + off farm + non-farm activities at $1 \%$ probability level. This indicated that those farmers with high educational level are more likely diversify livelihood strategies into on farm + non-farm and on farm + off farm + non-farm activities. This is due to most probably educated person gain better skill, experience, knowledge and this again help them to engage in diversified livelihood strategies. The marginal effect revealed, the likelihood of a household diversifying into on farm + non-farm and on farm + off farm and on farm + off farm + non-farm farm activities increase by $5.4 \%, 3.7 \%$ and $0.581 \%$, respectively for those farmers with more level of education. In other words, additional one year education can increase the chance of choosing on farm + non-farm and on farm + off farm and on farm + off farm + non-farm farm activities. This is in line with study by Birhanu and Getachew (2016) that education is very important variable that can help farmers to diversify the rural economy other than agriculture.

Total livestock owned (TLUOWNED): The ownership of livestock in TLU negatively and significantly correlated with livelihood diversification into on farm + off farm, on farm + non-farm, and on farm + off farm + non-farm activities at 5\% probability level. The negative association between livelihood diversification and number of TLU might be herd size creates better opportunity to earn more income from livestock production. This is confirmed by key informants that the majority of farmers depend on livestock production for their farm income. This demonstrated that a household having larger size of livestock are less likely to diversify the livelihood strategies into non-farm and/or off-farm activities. The marginal effect results of the model revealed, keeping other variables constant, the likelihood of diversifying the livelihoods into on farm + off farm, on farm + non-farm and on farm + off farm + non-farm activities decrease by $14.9 \%, 8.6 \%$, and $0.446 \%$ respectively, for households with more livestock number in TLU. This is consistent with study by Yishak G et al., (2014) that farmer with lower livestock holding would be obliged to diversify livelihoods into off and non-farm in order to meet needs.

Training and extension service (TAEXS): This variable has a positive and significant effect on livelihood diversification into on farm + non-farm, on farm + off farm and on farm + off farm + non-farm livelihood strategies at $1 \%$ probability level. This shows households who get training and extension service are more likely to be 
engaged into different combination of livelihood diversification strategies. The marginal effect results of the model showed that, factors are constant, the likelihood of diversifying into on farm + non-farm, on farm + off farm and on farm + off farm + non-farm livelihood activities increased by $46.5 \%, 11.2 \%$ and $4.649 \%$ respectively for those who gained training and extension service than the contrary. It is in line with the study by Asfaw et al., (2015); the extension service provides the necessary information so that farmers are able to acquire new skills and knowledge that helps to improve production and participate in different livelihood diversification to improve food security but contradicts with the study by Yishak(2014), found households' participation in agricultural training most likely decreases the likelihood of livelihood diversification into combing non-farm with off-farm activities because training enhances agricultural production skills, knowledge and experiences of farmers.

Access to credit (ACR): This was found to have a positive and significant effect on the level of livelihood diversification strategies into on farm + non-farm, on farm + off farm and on farm + off farm + non-farm livelihood activities at $1 \%$ probability level. This indicated that households who get credit access are more likely to be engaged into different livelihood activities than who did not get. Marginal effects result of the model revealed that, other things being constant, the likelihood of choosing on farm + non-farm, on farm + off farm and on farm + off farm + non-farm activities increased by $41 \%, 12.5 \%$ and $2.774 \%$ respectively for those who get credit access than their counterparts. Since resource-base is very poor for most of the rural households, providing credit to households will improve their livelihoods. This finding is in line with the study by Ambachew et al., (2016);credit access is found have a positive impact on likelihood of choosing livelihood diversification strategies and Birhanu (2014); credit is an important component, which can help the poor households undertake various types of livelihood strategies.

Market access (MKTA): This variable negatively and significantly affected the diversification of livelihood into on farm + non-farm, on farm + off farm, on farm + non-farm + off farm activities at $10 \%$ and $5 \%$ probability levels. This result suggests that a household residing in far distance to market are less likely to diversify the livelihood strategies into on farm + off farm, and on farm + non-farm activities. The negative association between livelihood diversification and market access indicated that households residing in the villages distant from market centers have less access and opportunity to engage into diversification activities. According to the study, keeping all other variables in the model held constant, the likelihood of diversifying the livelihoods into on farm + nonfarm, on farm + off farm and on farm + off farm + non-farm activities decreases by $3.2 \%, 3.8 \%$ and $0.246 \%$ respectively for increasing one additional unit in KM from their respective villages. The possible reason for the result could be households far from market places have no easy and quick physical access to the market, to transport output and input from and to their residence and the chance of wage labor, and small business (petty trade) for the diversification. This is in line with the study by Nigussie(2017) and Muluken(2009) that household who have been living around and have access to market centers have higher involvement in livelihood diversification and are able to diversify their sources of income than those households living far from market centers.

\section{CONCLUSIONS AND RECOMMENDATION}

Conclusion

As agriculture is the main stay of Ethiopian economy, government has been paying attention to the sector. But other livelihood diversification strategies have been overlooked in the rural development policies and strategies of the country. However, there is evidence that diversification strategies are growing up. Thus, the rural economy is beyond just farming. Rural households in the study area engaged into different combination of livelihood diversification activities to ensure their food needs. The Multinomial logistic regression model results revealed that seven explanatory variables were found to be significant determinant factors up to less than $10 \%$ probability level. Thus, livelihood diversification strategies in the study area were positively determined by the sex of the household head, education, credit access and training and extension service whereas negatively determined by age, livestock owned and market access.

\section{Recommendation}

Based on the findings of this study, the possible areas of intervention which might help to adopt best alternative livelihood diversification strategies in the study area in particular and other similar context in general.

- Intervention is needed for the female headed households to enable and empower them to participate in different livelihood diversification activities.

- Building capacity and creating awareness for aged households can increase their capacity to take risk; and that will ultimately improve their choice to participate into non-farm/off farm activities besides farm activity.

- Due attention should be given in promoting farmers' education through strengthening and establishing both formal and informal education, farmers' training centers, expanding technical and vocational schools.

- The local, regional governments and non-governmental organizations should focus on productivity of 
livestock sector through improving livestock breeds, veterinary services, forage development, marketing, access to credit and overall management of livestock production that aimed at improving rural household's welfare in general and particularly food security.

- Credit facilities should be improved and made easily accessible by households along with follow up of its effective utilization that they use for productive purpose rather than consumption.

- The government and non-governmental organizations should provide training and extension service to rural households and monitoring of extension agents needed.

- Access to markets should be established for rural producers in addition to ensuring the access to information on market opportunities and provision of rural infrastructures such as access to road is essential to reduce disparities of transaction costs for distant rural households.

- The government of Ethiopia should develop comprehensive rural development policy that could empower off-farm and non-farm rural livelihood diversification strategies besides the farm activities

\section{REFERENCES}

Adugna, E. (2012). Determinants of livelihood diversification in pastoral societies of southern Ethiopia. http://www.onlineresearchjournals.org/JABRJABR.

Ambachew, M.D. and Ermiyas, A. (2016). determinants of rural household livelihood diversification strategy in South Gondar zone, Ethiopia. Journal of Agricultural Economics, Extension and Rural Development: ISSN2360-798X, Vol. 4(8):; pp, 548-560.

Asfaw, S., McCarthy, N., Paolantonio, A., Cavatassi, R., Amare, M. and Lipper, L.(2015). Livelihood diversification and vulnerability to poverty in rural Malawi. Agricultural Development Economics Division Food and Agriculture Organization. ESA Working Paper (pp. 15-20), Rome.

Babatunde, R.O., (2013). On-Farm and Off-farm Works: Complement orSubstitute? Evidence from Rural Nigeria. Contributed paper for the 4th International Conference of the African Association of Agricultural Economists September 22-25, 2013. Hammamet, Tunisia. URL:Economists, Septehttp://ageconsearch.umn.edu. Accessed on June 10, 2014.

Berger, M.P. and Wong, W.K., (2009) An Introduction to Optimal Designs for Social and Biomedical Research. Willey, Chichester. https://doi.org/10.1002/9780470746912.

Birhanu, N., (2014). The role of irrigation development in enhancing household food security: A study of two small scale irrigation schemes in Bale Zone, Ethiopia, $\mathrm{PhD}$ Thesis.

Birhanu, N. and Getachew, D.,(2017).Livelihood Diversification: Strategies, Determinants and Challenges for Pastoral and Agro-Pastoral Communities of Bale Zone, Ethiopia. International Review of Social Sciences and Humanities, pp. 48-49.

Chilot Y. (2007). The daynamics of soil degradation and incentives for optimal management in Central Highlands of Ethiopia. PhD. Dissertation. University of Pretoria.

Davis, S.R., (2003). Rural Non-Farm Economy: Livelihoods and their Diversification, issues and options. NRI Report No. 2753

De Vaus, D. (2001). Research design in social research. London, California and NewDelhi: SAGE Publications Ltd.

Ellis, F. and Allison, E. (2004). Livelihood Diversification and Natural Resource Access. Food and Agriculture Organization of the United Nations, Livelihood Support Programme Working Paper 9, Overseas Development Quintile, University of East Anglia, January. Retrieved january 2004, from http://www.fao.org/es/esw/lsp/cd/img/docs/lspwp9.pdf (Accessed 6 January 2014).

Food and Agriculture Organisation (FAO). (2017). Severe food insecurity in Southren Somali Region due to prolonged drought.

FEWS NET. (2016). Largescale food security emergency projected for Ethiopia October2016. FEWS NET: Wshington:.

Greene, William H., (2003). Econometric Analysis. Fifth Edition. Prentice Hall: USA.

Gujarati, Damodar N.,(2004). Basic Econometrics (4th ed.). New York: The McGraw-Hill Campanies.

Jirstrom,M. Andersson A, Djurfeldt G., (2011). Smallholders caught in poverty-flickering signs of agricultural dynamism. In AfricanSmallholders: food crops, markets and policy. london.

John C. (2002). Good Practices in the Organisation and Management of Statistical Systems' for ASEAN countries, Yangon Myanmar, Dec.11-13.

Ken, B. (2004).Business Statistics for Contemporary Decision Making (Fourth (Wiley Student Edition for India) ed.). Wiley-India. HYPERLINK "https://en.wikipedia.org/wiki/International_Standard_Book_Number" \o "International Standard Book Number" ISBN - HYPERLINK "https://en.wikipedia.org/wiki/Special:BookSources/978-81-265-0809-9" lo "Special:BookSources/978-81265-0809-9" 978-81-265-0809-9.

Krishna, W. and Ranga, N., (2005). Creating and Harnessing social capital. In Dasgupta, P. and I.Seragdldin, 
Social capital: a multifaceted persepective. The World Bank, Washington, D.C.

MOFED. (2016). Federal Democratic Republic of Ethiopia. Food Security Programme 2010 - 2014. Addis Ababa, Ethiopia.

Muluken, Y. (2009). Market Access and Livelihood Diversification in Rural Areas: A Case Study in Kewot woreda, North Shoa Zone, Ethiopia. Unpublished MA Thesis. College of Developmental Studies. Addis Ababa University.

Nigel L. (2018). The average survey response rate[2018 benchmark] .

Nigussie, A. (2017). Determinants of Rural Livelihood Strategies: The Case of Rural Kebeles of Dire Dawa Administration. ISSN 2222-1697 (Paper) ISSN 2222-2847 (Online)Vol.8

NPC. (2017). The 2017 Voluntary National Reviews on SDGs of Ethiopia: Government Commitments, National Ownership and PerformanceTrends.

Shitarek T (2012). Ethiopia Country Report, Addis Ababa, Ethiopia.Available online at:https://www.gov.uk/government/uploads/system/uploads/attachment_data/file/197474/Econ-Res (accessed June, 2013).

Tassew, W. (2002). Income diversification and entry barriers: evidence from the Tigray region of northern Ethiopia. .

Tezera, M. (2010). Determinants of Rural Households Livelihood Diversification: The case of LibokemkemWoreda, Amhara region. Addia Abeba: AAU.

WAO. (2017). Kecha Bira woreda agricultural office report.

Williams. (2012). Hetroscedasticity. University of Notre Dame.

World Bank (2008). Agriculture for Development Policy. Washington, D.C: World Bank. pp. 177-179.

Workneh, N. (2008). Food Security Strategy and Productive Safety Net Program. Digest of Ethiopia's National Policies, Strategies and Programs, Pp 1-22. Forum for Social Science: Addis Ababa. Ethiopia.

Yemane, T., (1967). Statistics: An Introductory Analysis, 2nd Ed. New York: Harper and Row.

Yisehak, G.,Gezahegn, A., Tesfaye, L., Dawit, A., (2014). Rural household livelihood strategies: Options and determinants in the case of Wolaita Zone, Southern Ethiopia. Social Sciences Research,3.doi: 10.11648/j.ss.20140303.15, 92-104. 